\title{
Social Factors Influencing the Goat Farmers Knowledge of Waste Processing in Banyumas Regency, Central Java, Indonesia
}

\author{
Krismiwati Muatip*, Hermin Purwaningsih, Lis Safitri, and Aris Dwi Pamungkas \\ Faculty of Animal Science, Jenderal Soedirman University, Purwokerto, Central Java, Indonesia \\ *Corresponding author.Email: krismiwati.muatip@unsoed.ac.id
}

\begin{abstract}
Goat farming produced environmental pollution from livestock waste. On the other hand, the waste has economic value after being processed into compost. The farmers should not only be able to grow the goat but also process the waste into compost. The study aimed to analyze the influence of duration being a farmer, the level of education of farmers, and the number of goats on the farmer's knowledge of waste processing in the Banyumas Regency. The research used a survey method. The sample has been determined by multi-stage sampling. The number of 78 respondents have been selected from each village using the Slovin formula. Then, the data has been presented using the descriptive method and analyzed using Multiple Linear Regression analysis. The results showed that the duration of being a goat farmer was classified as the old category ( $>20$ years), the education level of goat farmers was categorized as low (elementary school), the number of goats was moderate (4-7 heads). Farmer's knowledge of processing goat waste was in the medium category. The level of education has a significant effect and the number of goats has a significant effect on the farmer's knowledge of waste management. The duration being farmer did not significantly affect the knowledge of farmers about the waste management.
\end{abstract}

Keywords: Goat farmer, Level of education, Farmer's knowledge, Compost.

\section{INTRODUCTION}

Goat farming not only produced high quality of meat but also the waste caused air and environmental pollution. Every goat produced $1.13 \mathrm{~kg}$ of manure every day. In other words, if the farmer has 5-10 goats, they will get 5.65-11.3 kg of dump every day [1]. Processing goat disposal into compost is expected to create cleaner goat farming and showed eco-friendly farming by reducing environmental pollutants. The other profitable of compost making is to increase farmer's income and to save production costs if used for their own agriculture.

Waste management needs proper knowledge, at minimum in compost making. The farmer could learn it through extension, online information, or other sources of information. Waste processing not only increased farmer's income but also developed their competence in the livestock business, since the human resources as an energy source [2]. Composting is a process in which organic matter biologically, especially microbes that use organic matter. Making compost regulates and controls this natural process faster. This process includes making a balanced mixture of ingredients, providing sufficient water, adjusting aeration, and adding a composting activator. Composting takes some days to weeks. Compost temperature increases along with the decomposition process of organic matter. Physical characteristics of compost include volume changed, discoloration, and texture changed [3].

This study aim 1) to find out the length being a farmer, the level of knowledge, and the average of the number of goats, 2) to find out the farmers' knowledge of waste processing, 3) to analyze the influences of the duration being farmers, the farmer's education level, and the number of goats on farmer's knowledge of waste processing in BanyumasRegency

\section{METHODS}

The research was conducted in Banyumas Regency, Central Java in 2019. The target of the study was goat farmers. The study used a survey method and 
multistage sampling to determine the sampling. Firstly, the area has been chosen using stratified random sampling by grouping the districts based on the level of population of goats (low, medium, high). There was one district has been selected from each stratum, with a total of three districts, namely Kalibagor as the highest level, Baturaden as the medium level, and Karanglewas as the lowest level. Secondly, one village was selected from each district using simple random sampling, namely Suro village (Kalibagor), Karangsalam village (Baturaden), and Tamansari village (Karanglewas). Thirdly, the number of 78 respondents has been selected by the Slovin formula with a margin error of $10 \%$.

The data has been obtained from observations and direct interviews with the goat farmers with the prepared questions. The descriptive analysis method was used to explain the duration of being a farmer, the education level, and the farmer's knowledge of waste management in the Banyumas Regency. Multiple Regression Analysis was used to determine the influence of the duration of being a farmer (X1), the farmer's level education (X2), and the number of goats (X3) on farmer's knowledge of waste management (Y) which calculated by the formula:

$\mathrm{Y}=\mathrm{a}+\mathrm{b} 1 \mathrm{X} 1+\mathrm{b} 2 \mathrm{X} 2+\mathrm{b} 3 \mathrm{X} 3$

\section{RESULT AND DISCUSSION}

\subsection{Goat Farming in Banyumas}

The farmer runs goat farming in simple and traditional methods. They built the goat cage from bamboo with iron sheeting roofing where located beside or behind the farmer's house. The condition of the cage also tends not to be considered clean. The slum cage is inhabited by around 5 goats. Livestock farming was not the primary job of the farmers. Usually, they worked as agriculture farmers, street vendors, or other jobs and made the animal farm a side job. Goats are small ruminants and are closely related to small farmers in rural areas. The existence of goats amid small communities was very helpful to increase the community's economy [4].

Since goat farming is a side job, the farmer earns money in uncertain amounts. Small livestock farms functioned to save farmers money to be sold when they meet an urgent need such as school funding, health need, etc. Therefore, the farmers did not have a certain target income from the goat farm [5]. Thus, goat farming would not develop and give stable income as far as placed as a sideline job [6].

\subsection{Social Factors of Goat Farmer}

\subsubsection{Duration of being Farmer}

Table 1, Goat farmers have been involved in goat farming

\begin{tabular}{|l|l|l|l|}
\hline Category & Score & $\begin{array}{l}\text { Number of } \\
\text { farmer }\end{array}$ & Percentage (\%) \\
\hline Low & $<10$ & 12 & 15.38 \\
\hline Medium & $10-20$ & 30 & 38.46 \\
\hline High & $>20$ & 36 & 46.15 \\
\hline Total & & 78 & 100 \\
\hline
\end{tabular}

The duration or length of being a farmer is a unit of time to measure how long the farmer has been involved in farming life. The duration of raising livestock should make them have better knowledge about the livestock business since they had a repetitive learning process from livestock activities.

Based on Table 1, goat farmers have been involved in goat farming for more than 20 years $(46.15 \%)$. The experience of raising goats should support the decisionmaking on the problems related to goats farming. The previous research said that the higher the experience of the farmer in their livestock activities, the sharper their intuition in predicting the conditions that will occur to their livestock business. Farmers are accustomed to overcoming these problems based on their experience during farming [7].

Goat farming was common for the rural people of Banyumas. Most of them prefer to raise goats as hereditary from their parents. The other reason was small goat farming is easy to maintain, there were only a few diseases that would attack goats to avoid losses and cost of health treatment, did not require special cages, need a small amount of money to start the business, and goats are suitable and easy to adapt to the rural environment. Goat farming is very suitable in agricultural land conditions because goats are known to be easy to adapt to various conditions of rural agroecosystems and are complementary businesses in the food crop farming system [8].

\subsubsection{The Level of Knowledge}

Education level is a formal learning process that has been obtained by farmers. Education influenced farmers both in thinking and practice [9]. The higher their education level the more dynamic in their thinking. 
Table 2. Level education of farmer

\begin{tabular}{|l|l|l|l|}
\hline \multicolumn{1}{|c|}{ Category } & Score & farmers & \multicolumn{1}{c|}{$\%$} \\
\hline Elementary school & 6 & 55 & 70.51 \\
\hline Junior high school & 9 & 12 & 15.38 \\
\hline Senior high school & 12 & 7 & 8.97 \\
\hline Diploma/undergraduate & $>15$ & 4 & 5.13 \\
\hline Total & & 78 & 100 \\
\hline
\end{tabular}

Based on Table 2, the majority of goat farmers in Banyumas Regency have been only graduated from elementary school, although some of them had a bachelor's degree. The low level of education caused the farmers in meeting difficulties to understand the innovation both in farming and non-farming areas. The difficulties in absorbing technology were in line with the levels of education. The higher the level of education of farmers the higher quality of human resources. Then, it influenced their work productivities [10].

The education level of farmers affected them to adopt the innovation, extension material, and supervision to increase their farm [11]. The low level of farmer's education was caused by their parents who did not care about education level and lastly intended to work simply in agriculture, farming, and small trading business [12].

\subsubsection{Number of Goats}

The number of goats is the number of goats owned by a farmer. Most farmers in Banyumas have 5 goats. The number showed their abilities to run the business and to earn income. The amount of money will be increased followed by the number of goats. Livestock productivity is one of the important factors to guarantee farmer's income [13].

Based on Table 3, the number of goat ownership in Banyumas Regency was in the medium category. Research conducted by Ekowati and Setyadi found that livestock ownership has a positive effect on farmers' income [14]. This is in line with another research which emphasized that the increase in livestock business income was determined by the number of livestock ownership, which affected the amount of livestock to be sold and livestock business income $[15,16]$.

The number of goats in Banyumas Regency tends to adjust farmers' ability to provide the forage and cage area. The foraging could be found around the farm and agriculture areas after they finished their regular job. Tuswati said that goat farmer in Gombong district was influenced by their habit in collecting forage every day to increase their livestock [17].

The result of this study showed that the amount of daily forage obtained by goat farmers in Banyumas
Regency is about 7-13 kg for 2-4 goats. They need around 3-4 hours after work to collect the grass because the distance is quite far. Based on the interviews with respondents, there were no farmers who have special land for growing forage for livestock. The farmer looked for a different area to collect the forage every day.

Table 3. Number of goats

\begin{tabular}{|l|l|l|l|}
\hline Category & Score & $\begin{array}{c}\text { Number } \\
\text { of Goats }\end{array}$ & Percentage (\%) \\
\hline Low & $<4$ & 23 & 29.49 \\
\hline Medium & $4-7$ & 41 & 52.56 \\
\hline High & $>7$ & 14 & 17.95 \\
\hline Total & & 78 & 100 \\
\hline
\end{tabular}

\subsubsection{Farmer's Knowledge of Waste Management}

Farmer's knowledge is the level of farmer's understanding about how to process the waste into compost. The information of farmer's knowledge of waste management in Banyumas Regency was obtained from extension workers and the farmers.

Farmer's knowledge has been measured by the indicator of general understanding of waste management, the benefit of compost, and compost processing. The farmer has already understood the general information of waste management and compost processing. However, they have already not practiced it yet in their waste management. The most common reason was processing compost was unusual for the farmer in Banyumas. Another reason was the farmer need more time to process the compost, while goat farming was their sideline. Moreover, they got a small amount of dump every day, so they prefer to spread it into agricultural land without any processing.

There were few farmers who have already used goat manure as compost in Indonesia [18]. Farmers who do not have agricultural land sold goat waste directly without any processing. The compost improves the physical, chemical, and biological properties of the soil, because it plays a very important role in triggering soil fertility in the form of supplying nutrients for autotrophic organisms (plants) and a source of energy for heterotrophic organisms (fauna and soil microorganisms) [19]. 
Table 4. Farmer's knowledge

\begin{tabular}{|l|l|l|l|}
\hline Category & Score & $\begin{array}{c}\text { Number of } \\
\text { farmer }\end{array}$ & $\begin{array}{c}\text { Percentage } \\
(\%)\end{array}$ \\
\hline Low & $<4$ & 6 & 7.59 \\
\hline Medium & $4-7$ & 52 & 66.67 \\
\hline High & $>7$ & 20 & 25.64 \\
\hline Total & & 78 & 100 \\
\hline
\end{tabular}

\subsubsection{The Influence of Duration being Farmer,} Education Level, and Number of Goats on Farmer's Knowledge of Waste Management

The effect of duration being farmer, the number of goats and farmer's education on farmer's knowledge of waste management has been analyzed using multiple linear regression analysis.

Table 5. Result of multiple linear regression analysis

\begin{tabular}{|l|l|c|}
\hline & \multicolumn{1}{|c|}{ Regression coefficient } & $t$ \\
\hline Constant & 3.403 & 4.427 \\
\hline Duration & 0.006 & 0.336 \\
\hline Education & $0.193^{\star}$ & 2.520 \\
\hline Number of goat & $0.207^{\star \star}$ & 2.741 \\
\hline
\end{tabular}

Table 5 showed that the duration of being a farmer had no significant effect on the farmer's knowledge of waste management. It happened because the farmers have no income-oriented in raising goats. Small goats farm intend to save the money and a sideline. The farmer imitated the methods practiced by their parents, even though they have been raising livestock for a long time.

Level education has a very significant effect on the knowledge of goat farmers of processing waste into compost. The farmers with fairly high education were easier to accept technological innovations both individually and in groups [20,21]. Farmer with higher education was always interested in improving their knowledge day by day. The higher the level of education, farmers tend to be braver to face various problems.

Goat farmers in Banyumas Regency have low education. Low education resulted in a lack of knowledge in utilizing available natural resources [22]. Goat feces in the community's livestock business have not been utilized optimally. Goat feces were packed in sacks for months, used as fertilization for crops without any processing.

The number of goat has a significant effect on the farmer's knowledge of waste management. This happened because the greater the number of goat, the more manure was produced. If the waste is not processed into compost, the manure will accumulate become an environmental pollutant. Then, the farmers tried to increase their knowledge of waste management deal with the amount of waste. In addition, compost processing increased their income in the livestock business.

The increasing the livestock population nationally and regionally will increase the waste produced [23]. It will transform into environmental pollution, especially from the sewage produced every day, if it is not managed well. The utilizing of livestock waste as organic fertilizer in crops is increasing recently. Good waste management is not only preventing environmental pollution but also providing additional value to the livestock business. The farmer's knowledge of compost processing tends to be already good. They should be motivated by extension workers to realize the compost processing.

\section{CONCLUSION}

The duration of being a goat farmer was classified as the old category (> 20 years). The education level of goat farmers was categorized as low (elementary school). The number of goats in Banyumas Regency was moderate (4-7 heads). Farmer's knowledge of processing goat waste was in the medium category. The level of education has a very significant effect \& the number of goats has a significant effect on the farmer's knowledge of waste management. The duration of being a farmer did not significantly affect the knowledge of farmers about waste management.

\section{REFERENCES}

[1] Rahmat MB, Putro JE, Widodo HA, Rakhmad C. Potential Sources of Renewable Energy and Organic Fertilizer from Livestock Manure in Sundul Magetan Village. Semin MASTER. 2018;3(1):175-82.

[2] Crook TR, Todd SY, Combs JG, Woehr DJ, Ketchen DJ. Does Human Capital Matter? A MetaAnalysis of the Relationship between Human Capital and Firm Performance. J Appl Psychol. 2011;96(3):443-456.

[3] Muhammad TA, Zaman B, Purwono P. The Effect of Addition of Goat Manure Fertilizer on Composting Results of Dry Leaves in Integrated Waste Disposal Sites of UNDIP. J Tek Lingkung. 2017;6(3):1-12.

[4] Nasich M. Crossbreed Goat Productivity from Boer Males and Local Parent (PE) in Pre-Weaning Period. J Trop Anim Prod. 2012;12(1):56-62. 
[5] Yunita D, Widyastuti R, Syamsunarno MRA, Rasad SD, Indika DR. Division of Roles and Decision Making in Dairy Goat Farmers' Households in Cilengkrang Village, Cimalaka District, Sumedang Regency. J Ilmu Ternak. 2017;17(1):21-6.

[6] Pakage S. Goat Farmer Income Analysis in Malang City. J Ilmu Peternak. 2013;3(2):51-7.

[7] Hasri LP, Suharyati S, Sulastri S. Estimated Output of Various Goat Nations in Dadapan Village, Sumberejo District, Tanggamus Regency. J Ris dan Inov Peternak. 2018;2(1):8-13.

[8] Rusdiana S, Hutasoit R. Increasing Goat Farming Business in Sumber Sari Farmer Group Study of Income Economic Analysis. Sepa J Sos Ekon Pertan dan Agribisnis. 2014;11(1):151-62.

[9] Hanurawan F. Cross-Cultural Psychology Study on Conformity Behavior. J Sains Psikol. 2018;3(1):18 .

[10] Febrina D, Liana M. Utilization of Agricultural Waste as Ruminant Feed for Smallholder Farmers in West Rengat District, Indragiri Hulu Regency. 2008;5(1):28-37.

[11] Edwina S, Cepriadi C, Zainina Z. Income Analysis of Broiler Farmers with Partnership Patterns in Pekanbaru City. J Peternak. 2006;3(1):1-9.

[12] Anggraini Fitria H, Lestari DAH, Adawiyah R. Income and Welfare of PE Goat Farmer Members and Non-Members of Farmer Groups in Sungai Langka Village, Gedung Tataan District,

Biology Resources Empowerment. J Sumberd Lahan. 2010;4(1):13-25.

[20] Muatip K, Sugiarto M. Farmer Children's Willingness for Dairy Farming Succession in Banyumas Regency. Anim Prod. 2016;18(2):11824.

[21] Muatip K, Purwaningsih H, Setianto NA, Sugiarto M, Widiyanti R, Safitri L, et al. Organizational Commitment of Members of the Dairy Farmer Group in Banyumas Regency. In: IOP Conference Series: Earth and Environmental Science. Institute of Physics Publishing; 2019.
Pesawaran Regency. J Ilmu Ilmu Agribisnis J Agribus. 2015;3(4):393-401.

[13] Nurhayati N, Jamil A, Anggraini RS. Potencies of Agricultural Waste as Local Organic Fertilizer in Lowland Dry Land Wet Climate. Iptek Tanam Pangan. 2011;6(2):193-202.

[14] Ekowati INWT, Setiadi A. Factors Affecting the Income of Kisar Sheep Farmers in Kisar Island, Southwest Maluku Regency. Agromedia Berk Ilm Ilmu-ilmu Pertan. 2016;34(2):54-64.

[15] Priyanto D, Adiati U. Analysis of Goat Farming Factors in Supporting Farming Diversification Patterns in Rural Areas. Pusat Penelitian Dan Pengembangan Peternakan. Bogor: 2008. p. 565671.

[16] Safitri L, Nuskhi M, Muatip K, Purwaningsih H, Setiana L. The Relationship between Human Being and Animal: The Study of the Concepts of Khalifah and the Animals in the Quran. Anim Prod. 2018;20(3):211-5.

[17] Tuswati DSSE. Profile and Characteristics of Goat Farmers on the Slopes of the Gombong Karst Mountains-Central. 2017;12(2):153-8.

[18] Prihatiningrum DN. Application of the Java Randu Goat Farming Agribusiness System in the Framework for Regional Development of Karangpucung District, Cilacap Regency. J Wil dan Lingkung. 2013;1(2):141-56.

[19] Subowo G. Efficiency Strategy of Organic Matter Use for Soil Fertility and Productivity by Soil

[22] Pratomo H, Prasetyo B. Compost Making from Goat Feces using Effective Microorganism (EM4), an Abdimas Activities in Tegal Village. In: Prosiding PKM-CSR Konferensi Nasional Pengabdian kepada Masyarakat dan Corporate Social Responsibilty. 2018. p. 403-12.

[23] Kusuma ME. The Effect of Several Types of Manure on the Quality of Bokashi. J Ilmu Hewani Trop. 2012;1(2):41-6. 